\title{
KIGELIA AFRICANA AND BOSWELLIA SERRATA AMELIORATE DIABETIC NEPHROPATHY IN STREPTOZOTOCINE - INDUCED DIABETIC RATS
}

\author{
TAREK KAMAL ${ }^{1}$; NASR EL-SAYED NASR ${ }^{1}$; IBRAHIM FATTOUH ${ }^{1}$; DOAA DORGHAM ${ }^{1}$; \\ MUSTAFA SHUKRY ${ }^{2}$ and KHALED KAHILO ${ }^{1}$ \\ ${ }^{1}$ Department of Biochemistry, Faculty of Veterinary Medicine, Kafrelsheikh University, \\ Egypt, Fax: +2(047)-3231311 \\ ${ }^{2}$ Department of Physiology, Faculty of Veterinary Medicine, Kafrelsheikh University, Egypt.
}

Received: 28 June 2017; $\quad$ Accepted: 31 July 2017

\begin{abstract}
Diabetic nephropathy is a life-threatening complication in both type 1 and type 2 diabetes. Kigelia africana and Boswellia serrata have been used in treatment of a wide variety of diseases, including diabetes and other inflammatory diseases. This study aimed to study the effect of Boswellia and Kigelia extracts on experimental diabetic nephropathy in rats and their mechanism of action. Eighty adult Sprague-Dawley rats were distributed into four groups 20 animals each. One group was left as a healthy control. Experimental diabetes was induced in the other groups by using streptozotocin for 4 weeks; the $2^{\text {nd }}$ diabetic control group was left without treatment. The $3^{\text {rd }}$ group received Kigelia extract while the $4^{\text {th }}$ one was treated by Boswellia extract. Blood samples and kidney specimen were collected and subjected to biochemical and histopathological analysis. In the treated animals, the results showed significant improvement in blood glucose level, serum albumin, creatinine and urine microalbumin. Parallel histopathological examinations revealed that the used plants extracts ameliorated the pathological changes of the diabeteic nephropathy including the glomerular sclerosis; glomerular area and tuft area compared to untreated group. IL-6 and IL-10 expression were improved in the treated group. These results indicate that both Boswellia and Kigelia extracts minimize the lesions of diabetic nephropathy and could be useful in improving the pathological alterations of parenchymal organs associated with diabetes.
\end{abstract}

Key words: Kigelia extract, Boswellia extract, diabetes, Kidney.

\section{INTRODUCTION}

Diabetic nephropathy (DN) is a consequent serious and progressive fate of microvascular complications of either type 1or type 2 diabetes mellitus since DN is the leading cause of end-stage renal disease (ESRD). The prominent features of DN include thickening of glomerular basement membranes, glomerular hyperfiltration, leading to mesangial extracellular matrix expansion, further increases in urinary albumin excretion, progression to glomerular and tubular sclerosis and renal failure (van Dijk and Berl 2004). Currently available therapies for diabetes include insulin and various oral antidiabetic gents such as sulfonylureas, biguanides, $\alpha$ glucosidase inhibitors and glinides. Among them, many products are expensive, not easily accessible and associated with several side effects. Alternatively, there is a growing interest in herbal remedies with more efficacious and safety for the treatment of DM (Krentz and Bailey 2005).

Corresponding author: Dr. NASR EL-SAYED NASR

E-mail address: nasr_157@yahoo.com

Present address: Department of Biochemistry, Faculty of Veterinary Medicine، Kafrelsheikh University, Egypt.
Medicinal plants showed beneficial effects and improved glucose homeostasis in diabetic patients (Huseini et al., 2012). The Kigelia plant has many therapeutic properties due to the presence of numerous secondary metabolites. These compounds include iridoids, flavonoids, naphthaquinones and volatile constituent, etc. Experimentally, the plant has shown antibacterial, antifungal, antineoplastic, analgesic, anti-inflammatory, antimalarial, central nervous system stimulant, anti-protozoal, antidiarrhoeal, and antioxidant properties (Saini et al., 2009). The ethanol extract of the steam bark inhibited the synthesis of prostaglandins and other inflammatory mediators which probably accounted for the analgesic and anti-inflammatory properties (Grace et al., 2002). The methanolic extract of Kigelia has an average free radical scavenging activity (comparable to that of Vitamin C) and phytochemical constituents which might be useful for further studies to unravel novel treatment strategies for diseases associated with free radical induced tissue damage (Nasiru and Oluwasegun 2014). Boswellia is a medicinal plant that has been traditionally used in India to treat various diseases including inflammatory conditions, arthritis, cardiac disorders and pain (Śallakī 2001). Moreover, 
Boswellia has successfully showed antiinflammatory, anti-cancerous and anti-ulcerous activities (Frank et al., 2009; Siddiqui 2011; Singh et $a l .$, 2008). It was reported that Boswellia olibanum gum has anti-hyperglycemic and anti-hyperlipidemic effects in streptozotocin induced diabetic rats (AlAwadi et al., 1991; Zutsi et al., 1986) against longterm diabetic complications (Rao et al., 2013). Furthermore, Boswellia opposed islet destruction and consequent hyperglycemia in an animal model of diabetes probably by inhibition of the production/action of inflammatory cytokines in an autoimmune process (Shehata et al., 2011). Therefore, in this study we investigated the role of two hypoglycemic herbs, Boswellia and Kigelia separately in protection against one of the most serious long term diabetic complications; diabetic nephropathy.

\section{MATERIALS AND METHODS}

\section{Animals and experimental Procedure}

Eighty adult Sprague-Dawley male rats with body weight ranging between 120-150 gm were purchased from an experimental animal centre, Kafrelsheikh University. Animals were properly maintained under well controlled standard conditions and were left for 2 weeks without any treatment for acclimatization. All the ethical issues were considered based on the Kafrelsheikh University Ethical Protocols on animal experiments. After 2 weeks, 20 animals were separated as a healthy control group while 60 rats were subjected to experimental diabetes induction by streptozotocine (Sigma Aldrich Co., Egypt). Streptozotocine was dissolved in sodium citrate buffer $(0.1 \mathrm{M}$ and $\mathrm{pH} 4.5)$ and diabetes was induced by a single dose (50mg/kg body weight) intraperitoneal injection of streptozotocine. Seventy two hours later, animals with blood glucose level above $250 \mathrm{mg} / \mathrm{dl}$ were selected as diabetic. Both healthy and diabetic rats were randomized into four groups of twenty rats each. Rats received vehicle or extract orally by stomach tube for four weeks as follows: Group I: Healthy untreated rats; group II: Diabetic control rats; group III: Diabetic rats treated by Kigelia africana and group IV: Diabetic rats treated by Boswellia serrata.

\section{Treatments:}

\subsection{Boswellia serrata}

Boswellia serrata extract was obtained from faculty of pharmacy, Mansoura University; Egypt. Briefly, it was originally prepared from a weight of $100 \mathrm{~g}$ purchased from a commercial source and powdered in electric mixer. The powder was extracted with distilled methanol ( $400 \mathrm{ml} \mathrm{X} \mathrm{5).} \mathrm{The} \mathrm{collected} \mathrm{extract}$ was dried under reduced pressure to give total extract (20 g), it was dissolved in $1 \%$ tween 80 and given orally by stomach tube by a dose $400 \mathrm{mg} / \mathrm{kg}$ body weight daily for four weeks (Azemi et al., 2012).

\subsection{Kigelia africana}

Kigelia africana extract was obtained from faculty of pharmacy, Mansoura University; Egypt. Briefly, 2 kg of fresh Kigelia africana fruits were sliced and extracted by soaking in $95 \%$ ethanol for 2 days with intermittent shaking, then the solvents were evaporated under reduced pressure on rotary evaporator and the total extract residue was used for research. The Kigelia africana was given dissolved in $1 \%$ tween 80 and was given daily by a dose 500 $\mathrm{mg} / \mathrm{kg}$ body weight for 4 weeks by stomach tube (Kumar et al., 2012).

\subsection{Sample collection and preparation}

Urine samples were collected once at the end of experiment, centrifuged at $3000 \mathrm{~g}$ for 20 minutes for removing any debris and kept frozen at $-20^{\circ} \mathrm{C}$ until determination of microalbumin. Blood samples were collected individually by a capillary tube from the medial canthus of the rat's eye. Serum was separated by centrifugation $(5 \mathrm{~min}, 5000 \mathrm{~g}$ ). Serum was kept at $-20{ }^{\circ} \mathrm{C}$ until assayed. After animal sacrifice, kidneys were quickly removed and washed with ice-cold isotonic saline; and properly cleaned of extraneous fat and connective tissue. Then left one was placed in $10 \%$ formalin in accordance with the subsequent histological protocols. Meanwhile, the other kidney was kept under $-80^{\circ} \mathrm{C}$ following the subsequent polymerase chain reaction (PCR) protocols.

\subsection{Biochemical assays}

Commercially purchased kits (BioSystem, Spain) were used for determination of serum glucose level based on (Trinder 1969), serum creatinine level using (Fabiny and Ertingshausen 1971) and serum albumin according to (Doumas et al., 1971). Microalbumin was measured in urine using microalbumin kits (BioSystem, Spain) according to (Cambiaso et al., 1988).

\subsection{Histopathology}

After sacrificing animal, left kidney was quickly removed and washed with ice-cold isotonic saline; it was placed in $10 \%$ formalin. The kidney specimens were sectioned at $1 \mu \mathrm{m}$ thickness and stained with Periodic acid Schiff (PAS) to evaluate the possible histopathological changes of the kidney of the different groups at the $1^{\text {st }}$ and $4^{\text {th }}$ week; they were examined for histopathological changes under the microscope (Leitz DMRBE, Germany). Images were taken with a digital camera (Leica DFC 295) at original magnification of $\mathrm{X} 400$. The sclerosis grade was scored by two people in a double-blinded fashion. The gromerular area and tuft area were measured by using the J-image software.

\subsection{Ribonucleic acid RNA extraction}

Total ribonucleic acid (RNA) was isolated from 50 mg kidney using Trizol (Invitrogen Company). Briefly, the right kidney was homogizied with $1 \mathrm{~m}$ 
Trizole, incubated at $15-30^{\circ} \mathrm{C}$ at room temperature for $5 \mathrm{~min}, 200 \mu \mathrm{l}$ chloroform was added. The mixture was shaken for $30 \mathrm{sec}$ followed by centrifugation at 13000 $\mathrm{g}$ at $4{ }^{\circ} \mathrm{C}$ for $15 \mathrm{~min}$. The supernatant layer was transferred to a new tube, and an equal volume of isopropanol was added to the sample, shaken for 15 $\mathrm{sec}$ and centrifuged at $13000 \mathrm{~g}$ at $4^{\circ} \mathrm{C}$ for $10 \mathrm{~min}$. The ribonucleic acid pellet was washed with $70 \%$ ethanol, and then dissolved in 20-50 $\mu$ l of RNase free water. The prepared ribonucleic acid RNA was checked by electrophoresis, which demonstrated the RNA integrity.

\subsection{Reverse transcriptase -polymerase chain reaction ( $R T-P C R)$}

Complementary Deoxyribonucleic acid (cDNA) was synthesized by a mixture of $1 \mu \mathrm{g}$ total RNA, $2 \mu \mathrm{l}$ Oligo dT(0.5 ng) and $2 \mu \mathrm{l}$ nucleoside triphosphate dNTP $(2.5 \mathrm{mM})$ incubated at $70^{\circ} \mathrm{C}$ for 5 minute in a total volume $25 \mu \mathrm{l}$ RNase- free $\mathrm{ddH}_{2} \mathrm{O}$, then cooled on ice immediately for 2 minute, then added $4 \mu \mathrm{l}$ RTbuffer $(5 \mathrm{X}), 0.5 \mu \mathrm{l}$ RNasin $(40 \mathrm{u} / \mu \mathrm{l})$ and $1 \mu \mathrm{l}$ reverse transcriptase enzyme (Gene $\mathrm{ON}$ company), reincubated at thermal cycler at $42^{\circ} \mathrm{C}$ for 50 minutes and at $950 \mathrm{C}$ for 5 minutes to synthesis the DNA. For polymerase chain reaction (PCR), $2 \mathrm{X}$ master mix, specific primer for cytokine, $1 \mu \mathrm{g}$ DNA were mixed. The reaction was initiated by denaturation for one cycle at $95^{\circ} \mathrm{C}$ for $1 \mathrm{~min}$, followed by, denaturation at $94^{\circ} \mathrm{C}$ for $1 \mathrm{~min}$, and annealing at the proper temperature for $1 \mathrm{~min}$, and then extension at $72^{\circ} \mathrm{C}$ for $1 \mathrm{~min}$ for the proper number of cycles for each gene mRNA using a thermal cycler (Bio- Rad). Finally, the samples were incubated for $7 \mathrm{~min}$ at $72^{\circ} \mathrm{C}$ after the last cycle of amplification. The primers sequences for PCR reaction were shown in table 1 . PCR products were separated by electrophoresis using $1.5 \%$ agarose gels. Intensities of the bands were analyzed using the public image-j software.

\section{Statistical analysis}

All the data were expressed as Mean \pm SEM. Statistical analysis was carried out using one way Analysis of variance (ANOVA) (newman-keuls: compare all pairs of columns) to analyze the significance between the groups. A value of $\mathrm{P}<0.05$ was considered to be significant.

\section{RESULTS}

\section{Body weight}

It was clearly observed from the present study that, the mean values of bodyweight in diabetic group was significantly decreased than that of non-diabetic control group. There are significant ameliorates of body weight of diabetic treated group with Kigellia and Boswellia compared with control diabetic group at the 3rd week and the 4th week as shown in Table 2 .

\section{Biochemical findings}

Table 2 shows significant increase in blood glucose streptozotocine treated rats $(491.8 \pm 42.8)$ than healthy control group $(124.8 \pm 6.29)$ by the end of the $1^{\text {st }}$ week. However, after 4 weeks either Kigelia or Boswellia treatment significantly $(\mathrm{p}<0.05)$ reduced glucose level (243.8 \pm 42.24 and 369 \pm 28.41 respectively) compared with diabetic control group (507.5 \pm 28.14$)$. Similar significant $(\mathrm{p}<0.05)$ improvement was recorded in serum albumin after both extracts supplement compared with diabetic group. Regarding renal function indices, both Kigelia and Boswellia significantly reduced serum creatinine level $(p<0.05)$ by the end of the $4^{\text {th }}$ week of their supplement. Microalbumin in urine was significantly reduced after 4 weeks of either Kigelia or Boswellia treatment compared with the untreated diabetic group.

\section{Histopathological findings}

PAS glycoprotein specific stain was used to examine the kidney tissue sections. Consequently, slides in figure 1 revealed intense accumulation of PASpositive materials in the glomeruli of the kidney section from diabetic control in a time dependent manner when compared with non-diabetic controls. Meanwhile, Kigelia or Boswellia treatment slightly decreased the deposition of the PAS-positive materials in the glomeruli in $1^{\text {st }}$ week but by the $4^{\text {th }}$ week Kigelia or Boswellia treatment markedly reduced the deposition of the PAS-positive materials in the glomeruli as shown in Fig. 1. Glomerulosclerosis was evaluated at 1 st and 4 th week and expressed as sclerosis grades in Fig. 2A according to previous protocol (El Nahas et al., 1991). The sclerosis grade increased under diabetic conditions but was significantly decreased in the Kigelia or Boswellia treated group at $4^{\text {th }}$ week. Quantitative evaluation of the histological indices was then performed and there were no significant differences in the glomerular area among treated groups when compared with the diabetic control group at $1^{\text {st }}$ week but there was a significant decrease in the glomerular area in Kigelia treated group at $4^{\text {th }}$ week. However, Boswellia treatment reduced the glomerular area at $4^{\text {th }}$ week but not significantly as shown in Fig. 2B. There is non- significant difference in the tuft area among treatment groups compared with the diabetic control group at $1^{\text {st }}$ week. After the $4^{\text {th }}$ week, Kigelia or Boswellia treatment significantly reduced the tuft area compared with diabetic control animal as shown in Fig. 2C.

\section{IL-6 and IL-10 mRNA expression analysis by PCR}

Levels of mRNA of interleukin IL-6 and interleukin IL-10 were determined using semi quantitative RT PCR in comparison with the constitutively expressed gene GAPDH was used as an internal control. The results are demonstrated by representative bands in Fig. 3. The intensity of the bands exhibits that the IL6 mRNA was significantly expressed in renal tissue 
of untreated diabetic rats compared with healthy control group while IL-10 messenger ribonucleic acid mRNA expression level was higher in the two groups. While Kigellia or Boswellia treatment significantly reduced expression of IL-6 mRNA as compared with diabetic control group Kigellia treatment significantly up-regulated mRNA expression of IL-10. Interestingly, Boswellia treatment enhanced expression of IL-10 mRNA but insignificantly.

Table 1: Gene-specific primers for RT-PCR.

\begin{tabular}{ccccc}
\hline & & Sequence of primers & Annealing & Target $(\mathrm{pb})$ \\
\hline \multirow{2}{*}{ IL-6 } & Sense & 5'- CCA CTG CCT TCC CTA CTT CA -3' & 57 & 525 \\
\cline { 2 - 5 } & Antisense & 5'- GAAACGGAACTCCAGAAGAC- 3' & & \\
\hline \multirow{2}{*}{ IL-10 } & Sense & 5'-GGAGTGAAGACCAAAGG - 3' & 54.5 & 299 \\
\cline { 2 - 5 } & Antisense & 5'- TGG TCC TTA GCC ACT CCT TC -3' & & \\
\hline \multirow{2}{*}{ GAPDH } & Sense & 5'-CGGAGTCAACGGATTTGGTCGTAT-3' & 60 & 308 \\
\cline { 2 - 5 } & Antisense & 5'-AGCCTTCTCCATGGTGGTGAAGAC-3' & & \\
\hline
\end{tabular}

Table 2: Effect of Kigelia or Boswellia on Biochemical parameters and body weight.

\begin{tabular}{cccccc}
\hline Time/weeks & Groups & $\begin{array}{c}\text { Body } \\
\text { weight }\end{array}$ & $\begin{array}{c}\text { Blood } \\
\text { glucose }\end{array}$ & $\begin{array}{c}\text { Serum } \\
\text { albumin }\end{array}$ & $\begin{array}{c}\text { Serum } \\
\text { creatinine }\end{array}$ \\
\hline \multirow{2}{*}{$1^{\text {st }}$ week } & Normal & $169.4 \pm 6.83$ & $124.8 \pm 6.29$ & $5.242 \pm 0.34$ & $0.512 \pm 0.06$ \\
\cline { 2 - 6 } & Diabetic & $175.2 \pm 5.68$ & $491.8 \pm 42.8$ & $3.818 \pm 0.24$ & $1.36 \pm 0.17$ \\
\cline { 2 - 6 } & Kigelia & $174.2 \pm 5.28$ & $381.4 \pm 20.24$ & $4.937 \pm 0.36$ & $1.01 \pm 0.11$ \\
\cline { 2 - 6 } & Boswellia & $178.4 \pm 3.01$ & $443.6 \pm 44.97$ & $3.847 \pm 0.37$ & $1.176 \pm 0.16$ \\
\hline $2^{\text {nd }}$ week & Normal & $204.8 \pm 3.47$ & $126.2 \pm 4.85$ & $5.362 \pm 0.19$ & $0.5167 \pm 0.04$ \\
\cline { 2 - 6 } & Diabetic & $173.8 \pm 10.07$ & $499.4 \pm 32.56$ & $3.568 \pm 0.27$ & $1.567 \pm 0.16$ \\
\cline { 2 - 6 } & Kigelia & $198.8 \pm 9.31$ & $348 \pm 29.76^{* * *}$ & $4.873 \pm 0.16^{* *}$ & $0.95 \pm 0.02^{* *}$ \\
\cline { 2 - 6 } & Boswellia & $192.3 \pm 16$ & $423.6 \pm 29.6$ & $3.958 \pm 0.24$ & $1.308 \pm 0.10$ \\
\hline $3^{\text {rd }}$ week & Normal & $215.5 \pm 10.84$ & $121.3 \pm 5.02$ & $5.314 \pm 0.28$ & $0.6019 \pm 0.06$ \\
\cline { 2 - 6 } & Diabetic & $170.5 \pm 8.41$ & $502.3 \pm 14.46$ & $3.343 \pm 0.19$ & $1.509 \pm 0.08$ \\
\cline { 2 - 6 } & Kigelia & $205.3 \pm 5.89^{* *}$ & $286.3 \pm 50.29^{* * * *}$ & $5.155 \pm 0.17^{* * * * *}$ & $0.7685 \pm 0.04^{* * * *}$ \\
\cline { 2 - 6 } & Boswellia & $197.5 \pm 6.41^{*}$ & $395.8 \pm 31.28^{* *}$ & $3.912 \pm 0.18$ & $1.241 \pm 0.03^{* * *}$ \\
\hline $4^{\text {th }}$ week & Normal & $223.8 \pm 3.72$ & $119.5 \pm 5.635$ & $5.494 \pm 0.46$ & $0.575 \pm 0.06$ \\
\cline { 2 - 6 } & Diabetic & $151.3 \pm 8.93$ & $507.5 \pm 28.14$ & $2.974 \pm 0.15$ & $1.663 \pm 0.10$ \\
\cline { 2 - 5 } & Kigelia & $208.6 \pm 7.08^{* * * *}$ & $243.8 \pm 42.24^{* * * *}$ & $5.141 \pm 0.28^{* * * *}$ & $0.73 \pm 0.20^{* * * *}$ \\
\cline { 2 - 5 } & Boswellia & $200.6 \pm 7.77^{* * * *}$ & $369 \pm 28.41^{* * *}$ & $4.257 \pm 0.10^{* * *}$ & $1 \pm 0.09^{* * *}$ \\
\hline
\end{tabular}

Data are expressed as mean $\pm \mathrm{SE}(\mathrm{P}<0.05)$. Number of $(*)$ represents level of significance compared to diabetic group.

\section{FIGURE LEGENDS}

Fig.1: PAS staining of kidneys in the normal, diabetic, Kigelia treatment group and Boswellia treatment group. No Pathological changes were observed in the glomeruli the control group. However, the basement membrane was thickened and the mesangial matrix was increased in the diabetic group at 4 weeks. Slides from either kigelia or boswellia given groups showed recovering changes close to normal.

Fig.2: Histological evaluation of kidney: Glomerular area (A), Tuft area (B) and Sclerosis score (C) at $1^{\text {st }}$ and $4^{\text {th }}$ week of age in streptozotocineinduced diabetic rats. Data are expressed as mean \pm SE compared to diabetic group.

Fig .3: Upper panel: RT-PCR analysis by Agarose gel electrophoresis of mRNAs for IL-6, IL-10, and GAPDH in kidney tissue at 4th week of age. Lower panel: quantitative comparison represented by mean expression of mRNA For IL-6 and IL-10 / GAPDH products shown in the upper panel. Values are the mean of measurements $\pm \mathrm{SD}$. ${ }^{* *} \mathrm{p} \leq 0.01$ compared to IL-6 mRNA in diabetic group while $\neq p \leq 0.05$ compared to IL-10 mRNA in diabetic group. 


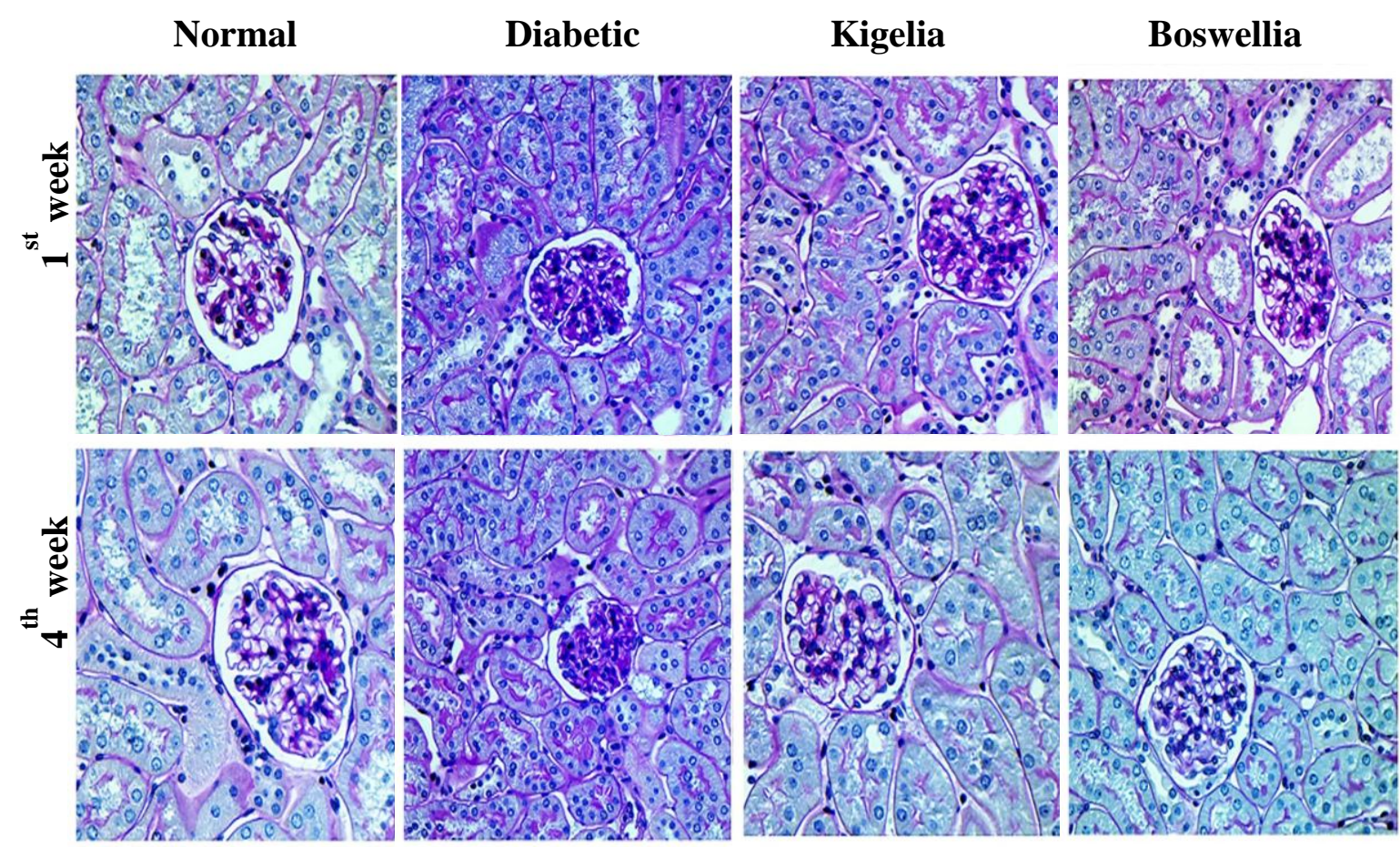

A

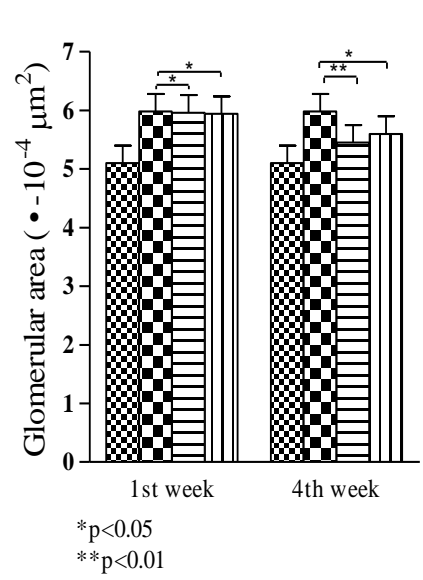

B

Normal

Kigelia

而 Boswellia

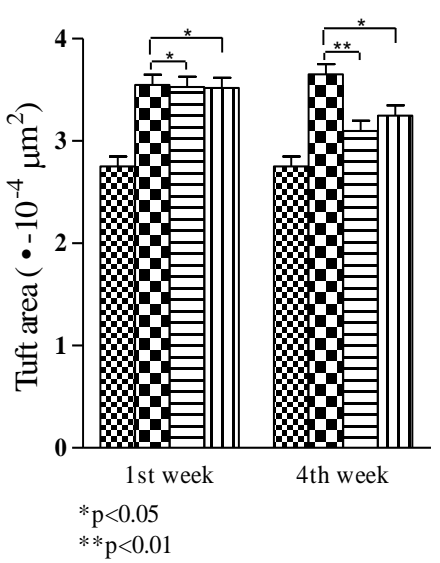

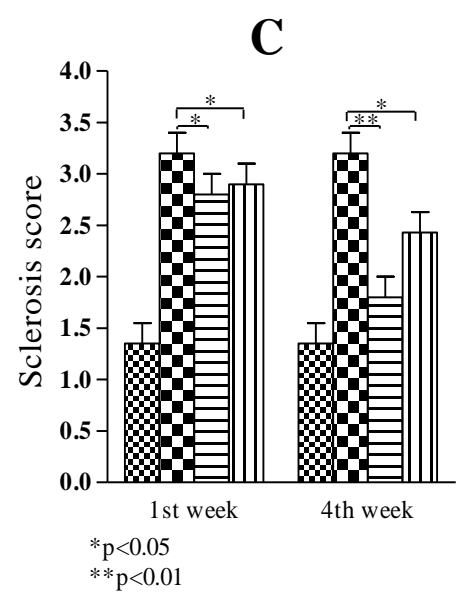



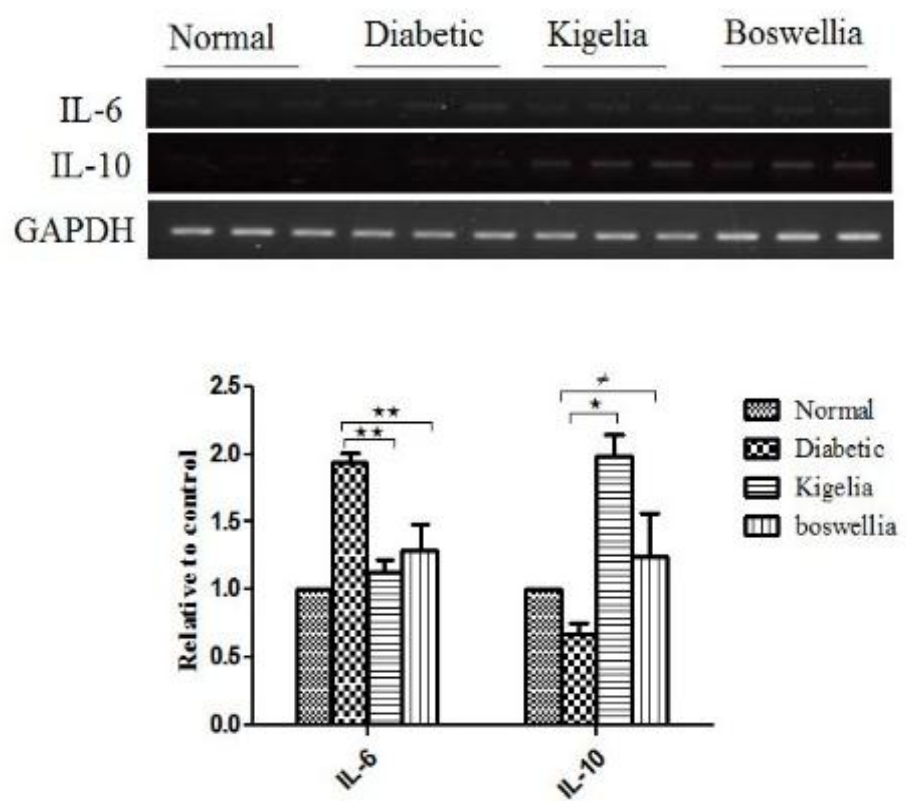

\section{DISCUSSION}

Streptozotocine has been used successfully in experimental diabetes induction via massive destruction of insulin unique producer, $\beta$-cells of the islets of Langerhans. Consequently, the survived laboratory animals demonstrated typical symptoms of diabetes starting with hyperglycemia and body weight loss in all animals, apart from healthy group, before treatment. The records are in accordance with previous similar studies on laboratory animals (Kumar et al., 2011). However, compared with placebo group, either Kigelia or Boswellia supplement markedly succeeded in lowering blood glucose level and in restoring body weight in the treated rats. Although the hypoglycemic effect of both Boswellia and Kigelia was previously reported its exact mechanism is still unclear and needs further investigation (Kumar et al., Shehata et al., 2011). It is suggested that their lowering blood sugar could be conducted through improving cellular insulin resistance and antagonizing the subsequent inflammatory processes. Our histopatholgical examination of kidney sections from diabetic rats compared with normal control group revealed detectable morphological changes in the glomeruli. The PAS, a glycoprotein specific stain, showed sclerosis of the renal tissue attributed to protein glycation. The glomerular morphological lesions along with significant high levels of serum creatinine, urine microalbumin and significantly upregulated expression of proinflammatory IL-6 mRNA indicated the development of $\mathrm{DN}$ in diabetic group. In agreement with our findings, it has been reported that chronic hyperglycemia enhances free radicals production and oxidative stress which leads to microvascular complications leading to damage in other organs including kidneys. One of the most damaging effects of free radical initiated lipid peroxidation, is destruction of cell membranes. Accordingly, development of diabetic nephropathy is characterized by glomerular hyperfiltration and thickening of glomerular basement membranes, followed by an expansion of extracellular matrix in mesangial areas and increase of urinary albumin excretion rate progresses to glomerular sclerosis associated with renal dysfunction (Sharma and Ziyadeh 1995). Unlike diabetic group, tissue sections from either Kigelia or Boswelia treated animals showed preserved undamaged renal tissue that was PAS negative. The preserving effect was reflected in significantly downregulated serum creatinine, urine microalbumin and the expression of IL- 6 mRNA. In contrast, the anti-inflammatory gene of IL-10 was upregulated. Our present study shows that either Kigelia or Boswellia supplement improved disorders of serum creatinine, serum albumin and urine microalbumin level that accompanied with diabetes. Also, either of them prevented the pathological changes that caused by diabetes including sclerosis grade, glomerular area and tuft area. These improvements may due to anti-oxidant and antihyperglycemia Protective effects of Boswellia extract, and hypoglycaemic, antioxidant effect and hypolipidemic effect of Kigellia extract (Nasiru and Oluwasegun 2014; Saini et al., 2013).

\section{CONCLUSION}

The present study concluded that either Boswellia or Kigelia not only has an antidiabetic effect but also has a renoprotective role and prevents development of DN. 


\section{ACKNOWLEDGEMENTS}

This study was supported, in part, by grant no. A1011 from the Science and Technology fund of Kafrelsheikh University, Egypt.

\section{COMPLIANCE WITH ETHICAL STANDARDS}

This study was done according to the ethical standard of Kafrelsheikh University

\section{REFERENCES}

Al-Awadi, F.; Fatania, H. Shamte, U. (1991): The effect of a plants mixture extract on liver gluconeogenesis in streptozotocin induced diabetic rats. Diabetes Res. 18, 163-168.

Azemi, M.; Namjoyan, F.; Khodayar, M.; Ahmadpour, F.; Darvish Padok, A. and Panahi, M. (2012): The Antioxidant Capacity and Anti-diabetic Effect of Boswellia serrata Triana and Planch Aqueous Extract in Fertile Female Diabetic Rats and the Possible Effects on Reproduction and Histological Changes in the Liver and Kidneys. Jundishapur J. Nat Pharm Prod. 7, 168-175.

Cambiaso, C.; Collet-Cassart, D. and Lievens, M. (1988): Immunoassay of low concentrations of albumin in urine by latex particle counting. Clin Chem. 34, 416-418.

Doumas, B.; Watson, W.; Biggs, H. (1971): Albumin standards and the measurement of serum albumin with bromcresol green. Clin Chim Acta. 31, 87-96.

El Nahas, A.; Bassett, A.; Cope, G. and Le Carpentier, J. (1991): Role of growth hormone in the development of experimental renal scarring. Kidney International. 40, 29-34.

Fabiny, D. and Ertingshausen, G. (1971): Automated reaction-rate method for determination of serum creatinine with the CentrifiChem. Clin Chem. 17, 696-700.

Frank, M.; Yang, Q.; Osban, J.; Azzarello, J.; Saban, M.; Saban, R.; Ashley, R.; Welter, J.; Fung, K.; Lin, H. (2009): Frankincense oil derived from Boswellia carteri induces tumor cell specific cytotoxicity. BMC Complement Altern Med. 9, 6.

Grace, O.; Light, M.; Lindsey, K.; Mulholland, D.; Van Staden, J. and Jäger, A. (2002): Antibacterial activity and isolation of active compounds from fruit of the traditional African medicinal tree Kigelia africana. South African Journal of Botany. 68, 220-222.

Huseini, H.; Kianbakht, S.; Hajiaghaee, R. and Dabaghian, F. (2012): Anti-hyperglycemic and anti-hypercholesterolemic effects of Aloe vera leaf gel in hyperlipidemic type 2 diabetic patients: a randomized double-blind placebo- controlled clinical trial. Planta Med. 78, 311316.

Krentz, A. and Bailey, C. (2005): Oral antidiabetic agents: current role in type 2 diabetes mellitus. Drugs 65, 385-411.

Kumar, R.; Pate, D.; Prasad, S.; Sairam, K. and Hemalatha, S. (2011): Antidiabetic activity of alcoholic leaves extract of Alangium lamarckii Thwaites on streptozotocin-nicotinamide induced type 2 diabetic rats. Asian Pac J. Trop Med. 4, 904-909.

Kumar, S.; Kumar, V. and Prakash, O. (2012): Antidiabetic and hypolipidemic activities of Kigelia pinnata flowers extract in streptozotocin induced diabetic rats. Asian Pac J. Trop Biomed. 2, 543-546.

Nasiru, A. and Oluwasegun, A. (2014): In Vitro Free Radical Scavenging Activity and Total Phenolic Content of Kigelia Africana (LAM). International Journal of Science and Research. 3, 368-370.

Rao, A.; Veeresham, C. and Asres, K. (2013): In vitro and in vivo inhibitory activities of four Indian medicinal plant extracts and their major components on rat aldose reductase and generation of advanced glycation endproducts. Phytother Res. 27, 753-760.

Saini, A.; Chauhan, P.; Singh, V. and Sharma, P. (2013): Phytochemical, Antioxidant \& in vitro Antibacterial Activity of Aqueous \& Ethanolic Fruit Extracts of Kigelia Africana. Indian J. Pharm. Biol. Res 1, 46-52.

Saini, S.; Kaur, H.; Verma, B.; Ripudaman, S. and Singh, K. (2009): Kigelia africana (Lam.) Benth: -an overview. Nat Prod Rad 8, 190197.

Śallakī, P. (2001): Boswellia serrata: Indian Medicinal Plants - Forgotten Healers: A Guide to Ayurvedic Herbal Medicine Chaukhamba Sanskrit Pratishth Publishers, Delhi.

Sharma, K. and Ziyadeh, F. (1995): Hyperglycemia and Diabetic Kidney-Disease - the Case for Transforming Growth-Factor-Beta as a Key Mediator. Diabetes 44, 1139-1146.

Shehata, A.; Quintanilla-Fend, L.; Bettio, S.; Singh, C. and Ammon, H. (2011): Prevention of multiple low-dose streptozotocin (MLD-STZ) diabetes in mice by an extract from gum resin of Boswellia serrata (BE). Phytomedicine. 18, 1037-1044.

Siddiqui, M. (2011): Boswellia serrata, a potential antiinflammatory agent: an overview. Indian J Pharm Sci. 73, 255-261.

Singh, S.; Khajuria, A.; Taneja, S.; Khajuria, R.; Singh, J.; Johri, R. and Qazi, G. (2008): The gastric ulcer protective effect of boswellic acids, a leukotriene inhibitor from Boswellia serrata, in rats. Phytomedicine 15, 408-415.

Trinder, P. (1969): Determination of blood glucose using an oxidase-peroxidase system with a 
non-carcinogenic chromogen. J. Clin Pathol. 22, 158-161.

Van Dijk, C. and Berl, T. (2004): Pathogenesis of diabetic nephropathy. Rev Endocr Metab Disord 5, 237-248.
Zutsi, U.; Rao, P. and Kaur, S. (1986): Mechanism of cholesterol lowering effect of Salai guggal exBoswellia serrata Roxb. Indian J. Pharmacol. $18,182-183$.

\section{كيجيليا أفريكانا والبوسويلية سيراتا يحسنان اعراض اعتلال الكلية السكري الناتج عن استحداث مرض السكري في الفئران بإستعمال ستريبتوزوتوسين اعتين الفينين}

طارق كمال ، نصر السبل نصر ، (بر/هيم فتوح ، دعاء ضرغام ، مصطفي شكري ، خالد كصيلو

E-mail: nasr_157@yahoo.com Assiut University web-site: www.aun.edu.eg

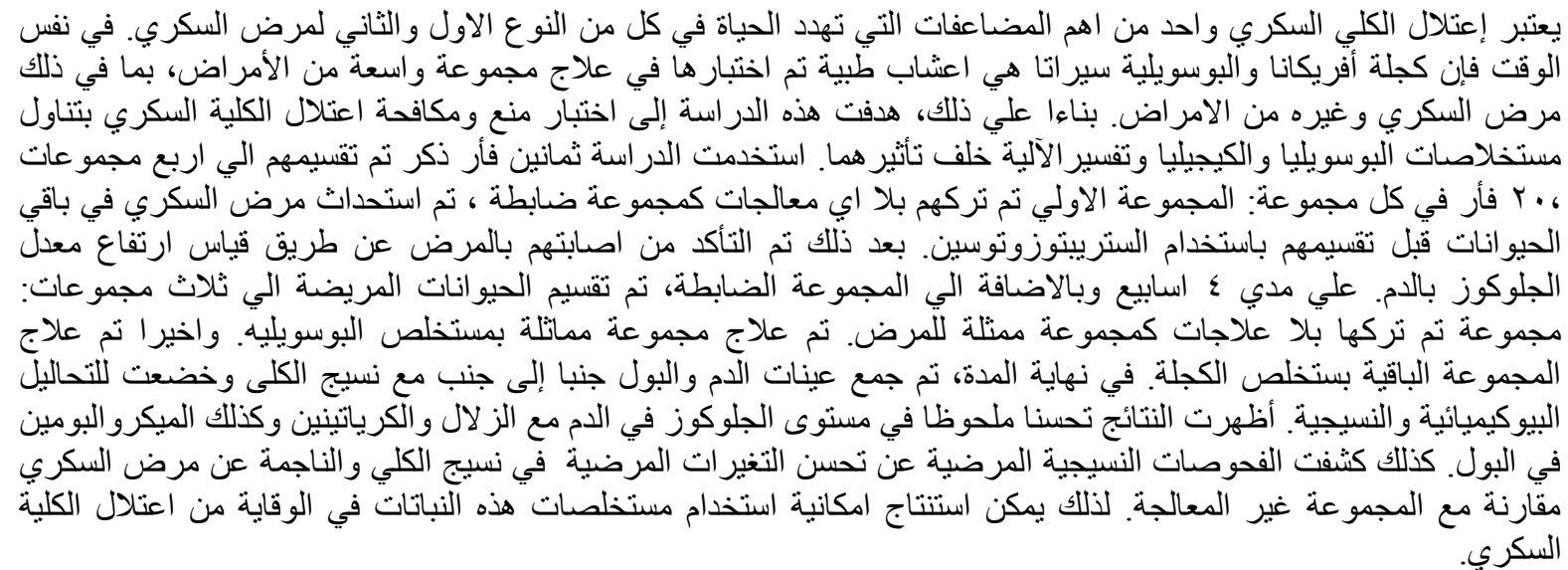

